TITLE:

\title{
Studies on Suppressor Cell Function in Thyroid Diseases( Abstract_要旨)
}

AUTHOR(S):

Aoki, Norihiko

CITATION:

Aoki, Norihiko. Studies on Suppressor Cell Function in Thyroid Diseases. 京都大学, 1979, 医学博士

ISSUE DATE:

1979-07-23

URL:

http://hdl.handle.net/2433/222249

RIGHT: 


\section{【162】}

氏 名青 杰矩彦

学位の種類医学 博 士

学位記番号論医 博 第 804 号

学位授与の日付”昭和 54 年 7 月 23 日

学位授与の要件 学 位 規則 第 5 条第 2 項該 当

学位論文題目 Studies on Suppressor Cell Function in Thyroid Diseases

（甲状腺疾患に和けるサプレッサー細胞機能に関する研究）

諭文調査委員 坠援 花岡正男 教授内野治人 教授鳥塚莞爾

\section{論文内容 の 要旨}

免疫学に呿ける最近の広範な研究により免疫現象も他の一般的生物現象と同じく二つの相対する因子 (ヘルパー因子，サプレッサー因子）により制御を受け恒常性を保持していることが判明している。自己 免疫現象はこの二つの因子のバランスが崩れた状態，すなわらサプレッサー細胞の機能低下であるとする 見解が主として動物実験により多数提出されている。本研究はこれらの基礎的事実をもとにして人間に拈 ける自己免疫疾患の代表的存在であるグレーブス病，橋本病に㧍いてサプレッサー細胞の機能を探索する ことを目標とした。

サプレッサー細胞の機能の探索はグレーブス病, 橋本病, 甲状腺癌各患者及び正常者につき各々末梢血 単核細胞（淋巴球，単核球）を分離してこれを下記の二種類の方法を用いて行なった。(1)はサプレッサー 細胞が in vitro で機能上比較的短命であるとする現象を利用したもので単核細胞の芽球化をみる培養系 に特いて 24 時間の前処置培養 $\left(37^{\circ} \mathrm{C}\right.$, 芽球化刺激物質不合)を受けた培養群がこれを和こなわない培養群 よりもコンカナバリン A (Con A) に対する芽球化反応がどの程度に克進するかを探索した。

(2)はコンカナバリンA と単核細胞を培養するとサプレッサー細胞が誘導され (Con A induced suppressor cell activity) この細胞を他の系に添加することによってこの系に元来あるべき免疫反応（芽球化現 象，抗体産生，細胞障害等広範囲にわたるが本研究では芽球化現象について検索した）が抑制されること を利用したもので, 前者の方法が末梢血で現在機能しているサプレッサー機能が推定されるのに対し, 後 者の方法は加光て潜在的サプレッサー機能も推定される。

このようなサプレッサー機能の検索はグレーブス病患者18例（未治療者 7 名, 抗甲状腺剤で治療中で且 つ血中甲状腺ホルモンレベルは正常域にあるもの 9 名, 抗甲状腺の治療の結果寬解状態にあり, 現在治療 をしていない者 2 名), 橋本病患者 8 名, 甲状腺癌患者（全例腺癌の他臓器への転移を有する） 6 名, 及 び14名の正常者に拈いて和こなって次の結果を得た。1.(1)(2)の測定法を通じてサプレッサー細胞の機能は 最終的培養系に加宎る刺激物質を至適濃度より低くすることによりより顕在化して認められる。2.(1)(2)の 測定法を通じてグレーブス病者では正常者に比しサプレッサー機能の低下が認められ，その程度は未治療 
の者により顕著であった。3.グレーブス病の同一症例について甲状腺剤による治療経過と共に検索すると サプレッサー機能の変動は必ずしも一様でなかった。4.グレーブス病者及び正常者について(1)(2)の指数は 相関を示した $(\mathrm{P}<0.01)$ 。 5 . 橋本病及び甲状腺癌患者では正常者に比しサプレッサー機能の有意の変動は 認められなかった。

結論として，サプレッサー機能の低下はグレーブス病者に認められたが，本機能の異常は HLA を含む 遺伝体質的異常であることが示唆された。同時に未治療グレーブス者にみるような機能え進状態がサプレ ッサー機能に影響を与兄ることも示唆された。

\section{論文 審 查の結果の要旨}

免疫反応一般を制御する suppressor 細胞の機能は一般免疫現象の他に免疫寛容性の維持及び自己免疫 現象の抑止にも重要な役割を担らとされている。著者は甲状腺自己免疫性疾患に拈いて， suppressor 細 胞の機能低下の有無につき検索することを目的とした。 suppressor 細胞機能の測定は患者の末梢血中の mononuclear cells について, (1)24時間の前培養が機能上比較的短命の suppressor 細胞の機能を除去す る現象，(2)concanavalin A でリンパ球を処置すると suppressor 細胞が誘導される現象のそれぞれを利 用しておこなった。結果として，(1)(2)の方法でみる suppressor 機能は健常者 Graves 病者についてみる 限り相関的数值を示した。疾病別にみると, 正常者と比し Graves 病群は有意に suppressor 機能が低下 していることが判明したが，橋本病及び甲状腺癌各群では正常者に比し差を見なかった。Graves 病群に 怙ける suppressor 機能は抗甲状腺剂使用群では未治療群に比し改善が認められたが，正常者に比較する とな抵下を示した。

以上の研究は甲状腺疾患の病態解明に寄与する所が多い。

よって, 本論文は医学博士の学位論文として価值あるものと認める。 